\title{
Growth hormone receptor gene expression in the skeletal muscle of normal and double-muscled bovines during foetal development
}

\author{
Anne LisTRAT ${ }^{\mathrm{a} *}$, Jean François HoCQUETTE ${ }^{\mathrm{a}}$, Brigitte PICARD ${ }^{\mathrm{a}}$, \\ François MÉNISSIER $^{\mathrm{b}}$, Jean DJIANE ${ }^{\mathrm{c}}$, Hélène JAMMES ${ }^{\mathrm{c}}$ \\ a INRA, Unité de Recherche sur les Herbivores, Equipe Croissance et Métabolismes du Muscle, \\ Theix, 63122 Saint-Genès-Champanelle, France \\ b INRA, Station de Génétique Quantitative et Appliquée, Domaine de Vilvert, \\ 78352 Jouy-en-Josas Cedex, France \\ c INRA, Neurobiologie de l'Olfaction et de la Prise Alimentaire, Bâtiment des Biotechnologies, \\ 78352 Jouy-en-Josas Cedex, France
}

(Received 13 August 2004; accepted 29 December 2004)

\begin{abstract}
The expression of the growth hormone receptor (GHR) gene was investigated in semitendinosus muscle during bovine foetal development in both normal and double-muscled Charolais foetuses which differ with respect to muscle development. Northern-blot analysis of foetal muscle RNA preparations with a GHR cDNA probe identified the $4.5 \mathrm{~kb}$ GHR mRNA as early as 130 days post-conception. In double-muscled animals, the expression of GHR mRNA increased from 130 to 210 days of gestation while it stayed stable in normal ones. It was significantly higher $(P<0.05)$ in double-muscled foetuses compared to normal ones from the second third of gestation. Northern-blot analysis of foetal muscle RNA preparations from both genotypes with a $\beta$-actin cDNA probe, revealed lower $\beta$-actin gene expression in double-muscled foetuses than in normal ones, suggesting a delay in the differentiation of muscle cells. In situ hybridisation revealed the localisation of specific GHR mRNA in muscle cells at all gestation stages analysed (130, 170, 210 days postconception) but not in connective tissue surrounding the muscle cells. At the adult stage, the hybridisation signal was also very high and observed in muscle cells only. These results show the ontogeny of GHR mRNA in bovine muscle and demonstrate a difference between normal and doublemuscled animals.
\end{abstract}

muscle / bovine / receptor / growth hormone / in situ hybridisation

\section{INTRODUCTION}

Some bovine breeds exhibit muscular hypertrophy which is under the control of the myostatin gene. In double-muscled animals, this gene, which is deleted in its coding sequence, has been identified by Grobet et al. [1]. The hypertrophy of some superficial muscles, which results from the presence of inactive myostatin, is the consequence of an increase in the total fibre number [2] due to hyperplasia [3, 4]. Picard et al. [5, 6] showed, in vivo and in vitro, that there was a variable delay in contractile differentiation of the

* Corresponding author: anne.listrat@clermont.inra.fr 
muscle of double-muscled (DM) animals. This delay occurred during the last third of foetal life. This delay could be due to effects of insulin like growth factors (IGF), mainly IGF-II. Indeed, these growth factors are known to play a role in muscle differentiation [7]. In addition, in a previous study, we showed that IGF-II mRNA were present in large amounts in foetal muscle cells [8]

In growing animals, growth hormone $(\mathrm{GH})$ is well known for its effects on growth of skeletal muscle and for its metabolic actions. In the foetus, although the concentration of growth hormone $(\mathrm{GH})$ in the circulation is high, it is established that it does not have a significant growth-regulatory function. For instance, anencephalic human foetuses [9] and hypophysectomised foetuses of numerous other species [10-12] appear to grow almost normally although they have little or no circulating immunoreactive GH. Nevertheless, a number of foetal tissues including skeletal muscle have been shown to respond to $\mathrm{GH}$ stimulation in vitro and in vivo [13-16] by an increase in protein synthesis and in myosin heavy chain expression at the mRNA level implying the presence of a functional $\mathrm{GH}$ receptor (GHR) during foetal development. The ontogeny of GHR gene expression in the foetuses of several species has been analysed by Northern-blot and RNAse protection assays. In foetal sheep, a major $4.4 \mathrm{~kb}$ transcript was detected [17] as early as day 51 of gestation in the liver, kidney, lung, heart, muscle and placenta. Its level increased slightly with advancing gestation. In the bovine foetus, Lucy et al. [18] reported the presence of GHR mRNA in several tissues, including the muscle and liver. In addition, both GHR mRNA and GHR protein have been detected in bovine embryos [19]. However, to our knowledge, ontogeny studies have never been conducted in cattle up till now.

Some authors showed that, on the one hand, a relationship exists between myostatin expression and $\mathrm{GH}$ action [20] and, on the other hand, between myostatin and IGF II expression [21]. One of the objectives of the present study was to investigate the ontogeny of GHR mRNA and to compare it to that of IGF-II [8] and myostatin [22] mRNA previously described in the same samples in our laboratory. In addition, in order to better understand the regulation of the differentiation of muscle fibres, we chose an hypertrophied muscle in double-muscled animals, the semitendinosus (ST) muscle. We determined the relative changes of GHR gene expression in double-muscled ST muscle, compared to normal ST muscle by Northern-blot and in situ hybridisation. This may be of high biological importance due to the association between myostatin expression and GH action [20].

\section{MATERIALS AND METHODS}

\subsection{Animals}

DM embryos of strain INRA95 [23] were transplanted into Charolais/Salers crossbreed cattle at a mean age of 2 years. Seven DM foetuses ( 2 at 130 days post-conception [d pc], 2 at $170 \mathrm{~d} \mathrm{pc}, 3$ at $210 \mathrm{~d} \mathrm{pc}$ ) were obtained from the transplantations. Their development was compared with 11 Charolais $\times$ Charolais/Salers (CS) foetuses $(4$ at $130 \mathrm{~d} \mathrm{pc}, 3$ at $170 \mathrm{~d} \mathrm{pc}, 4$ at $210 \mathrm{~d}$ pc) lacking the DM genotype, and produced by artificial insemination (the full gestational period for cattle is 280 days). Foetuses were produced at the INRA Research Centre and all the animals were slaughtered and samples were collected in compliance with ethical guidelines for animal care in this same centre (Theix, France).

\subsection{Samples}

Semitendinosus (ST) muscle and liver samples were taken from all foetuses. Adult ST muscle samples were taken from 5 mature cows ( 3 years of age after birth) and used as controls for in situ hybridisation. Tissue samples were removed immediately after exsanguination of the dam. Samples for 
in situ hybridisation were frozen in liquid nitrogen cooled isopentane then transferred to liquid nitrogen. Tissue samples collected for total RNA preparation were directly frozen in liquid nitrogen. All samples were stored at $-80^{\circ} \mathrm{C}$.

\subsection{Total RNA preparation}

Total RNA was extracted according to the method of Puissant and Houdebine [24]. After extraction, RNA was precipitated by the addition of $5.5 \mathrm{vol}$ of $4 \mathrm{M} \mathrm{LiCl}$, kept at $4{ }^{\circ} \mathrm{C}$ for $2 \mathrm{~h}$ and recovered by centrifugation $\left(5000 \times g, 20 \mathrm{~min}, 4^{\circ} \mathrm{C}\right)$. The pellet was dissolved in 2 vol of $10 \mathrm{mM}$ Tris- $\mathrm{HCl} \mathrm{pH} 7.5$, $1 \mathrm{mM}$ EDTA and $0.5 \%$ SDS. After one additional extraction by phenol:isoamylic alcohol-chloroform $\left(\mathrm{vol} \cdot \mathrm{vol}^{-1}\right)$, the aqueous phase was precipitated in the presence of $300 \mathrm{mM}$ sodium acetate and $2.5 \mathrm{vol}$ of ethanol. The RNA was stored in this precipitated form at $-20{ }^{\circ} \mathrm{C}$, until quantification by optical density measurements and analysis by Northern-blot.

\subsection{Probes}

A 600 bp fragment of bovine GHR cDNA (bGHR) was obtained from bovine hepatic mRNA using reverse transcription and a polymerase chain reaction (RT-PCR). Specific primers were derived from the bGHR cDNA previously published [25]. The sequence of the amplified fragment, coding the extracellular-, transmembraneand part of the intracellular- domains of bGHR, was verified by sequencing (Applied Biosystems DNA sequencing system, Foster city, USA), and was identical to the one previously published. This fragment was cloned in the pGEM18 plasmid.

\subsection{Northern-blot analysis.}

The RNA samples $(20 \mu \mathrm{g})$ of both normal and double-muscled animals were denatured in $2.2 \mathrm{M}$ formaldehyde, $50 \%$ formamide $\left(5 \mathrm{~min}, 65^{\circ} \mathrm{C}\right)$ and size-separated by electrophoresis in the same gel in agar- ose (1.5\%), 2.2 $\mathrm{M}$ formaldehyde in $10 \mathrm{mM}$ sodium phosphate buffer. RNA were transferred to the Zeta probe membrane (Biorad) by capillary blotting overnight under high ionic strength $(10 \times \mathrm{SSC}=1.5 \mathrm{M}$ sodium chloride, $0.15 \mathrm{M}$ sodium citrate). The bGHR DNA fragment and a mouse $\beta$-cDNA probe $(1 \mathrm{~kb})$ were labelled with $\alpha\left[{ }^{32} \mathrm{P}\right]-\mathrm{dCTP}$ (3000 Ci. $\left.\mathrm{mmol}^{-1}\right)$ (ICN, France) to a specific activity of $10^{8} \mathrm{cpm} \cdot \mu \mathrm{g}^{-1}$ DNA using a random priming kit (Roche). Used as a control, a rat $18 \mathrm{~S}$ ribosomal oligonucleotide probe was labelled at the 5'end with $\gamma\left[{ }^{32} \mathrm{P}\right]$-ATP using polynucleotide kinase as described by Hocquette et al. [26]. Membranes of muscle mRNA were first hybridised with the ${ }^{32} \mathrm{P}$ GHR cDNA probe, then they were stripped off (boiling in $0.5 \%$ SDS), before re-hybridisation with the ${ }^{32} \mathrm{P}$ labelled $18 \mathrm{~S}$ ribosomal oligonucleotide, then with the ${ }^{32} \mathrm{P} \beta$-actin cDNA probe. Autoradiograms were obtained by exposure to Amersham Hyperfilm with two amplified screens, at $-80^{\circ} \mathrm{C}$. Image analysis was performed on autoradiograms using the ChemiImager 5000 and the AlphaEase FluorChem software (Alpha Innotech Corporation, San Leandro, California, USA).

\subsection{In situ hybridisation}

The procedure for in situ hybridisation used was similar to that reported by Lyons et al. [27] with slight modifications. Briefly, frozen cross-sections of muscle and liver tissues were made using a 2800 Frigocut microtome (Reichert-Jung, Lahntechnik, Germany) and mounted on gelatincoated $(0.2 \% \mathrm{w} / \mathrm{v}$ gelatin $)$ slides. Foetal liver sections served as positive controls. The sections were fixed in $4 \%$ paraformaldehyde phosphate buffered saline solution followed by dehydration with absolute ethanol. Sections were stored, at $-80{ }^{\circ} \mathrm{C}$. Before hybridisation, the sections were rehydrated, treated with proteinase $\mathrm{K}$ (Sigma), fixed and acetylated with triethanolamine/acetic anhydride, washed and dehydrated. High specific-activity bGHR antisense RNA probes were transcribed 
from the linearised plasmid pGEM18 containing bGHR DNA fragment using $\left[{ }^{35} \mathrm{~S}\right]-$ UTP (specific activity $>1000 \mathrm{Ci} \cdot \mathrm{mmole}^{-1}$ ), (Amersham) and a SP6/T7 transcription kit (Roche). Sense strand cRNA probes were transcribed in the opposite direction under similar conditions. The resulting cRNA probes were reduced to $<100$ nucleotides using alkali hydrolysis and separated by gel filtration on a sephadex G-50 column (Pharmacia). Tissue cross sections, under cover slips, were hybridised in a humid chamber with $7.5 \times 10^{8} \mathrm{cpm} \cdot \mathrm{mL}^{-1}$ labelled bGHR cRNA probe in $50 \%$ deionised formamide, $0.3 \mathrm{M} \mathrm{NaCl}, 20 \mathrm{mM}$ Tris-HCl, pH 7.4, 5 mM EDTA, $10 \mathrm{mM} \mathrm{NaPO}_{4}, 10 \%$ dextran sulfate, $1 \times$ Denhardt solution, $100 \mathrm{mM}$ dithiothreitol (DTT), $100 \mu \mathrm{g} \cdot \mathrm{mL}^{-1}$ salmon sperm DNA at $42{ }^{\circ} \mathrm{C}$. Control slides were processed in an identical manner and probed with the corresponding sense GHR riboprobe. After hybridisation, the sections were washed once for $30 \mathrm{~min}$ at $50^{\circ} \mathrm{C}$ with $5 \times \mathrm{SSC}$ containing $10 \mathrm{mM}$ DTT then washed at $65{ }^{\circ} \mathrm{C}$ for $20 \mathrm{~min}$ with $50 \%$ formamide, $2 \times$ SSC, $10 \mathrm{mM}$ DTT. Section slides were then rinsed $10 \mathrm{~min}$. at $37^{\circ} \mathrm{C}$ in $1 \mathrm{M}$ Tris- $\mathrm{HCl}$ (pH 7.5) with $2 \times$ SCC, dehydrated and a $66 \%$ v/v LM1 nuclear track emulsion (Amersham) was applied. The slides were exposed for one week in light-tight boxes in the presence of desiccant at $4{ }^{\circ} \mathrm{C}$. Photographic development was performed using Ilford Phenisol (Ciba-Geigy).

\subsection{Statistical analysis}

All experiments were carried out in triplicate and all data were tested by variance analysis using the General Linear Model Procedure of the Statistical Analysis System [28]. Firstly, data of $18 \mathrm{~S}$ and of $\beta$-actin mRNA were analysed by testing the effect of age and genotype and the interaction between these two parameters. For $\beta$-actin and for GHR, the statistical analysis was performed with different approaches: (a) analysis of crude mRNA levels alone, (b) with $\beta$-actin or (c) with 18S RNA levels introduced as covariables in the statistical model as described by Hocquette and Brandstetter [29].

After analysing the results, we chose to use 18S RNA levels as a covariable to analyse GHR and $\beta$-actin mRNA levels. In the same model, we tested the effects of age and genotype and the effect of their interaction. All data were expressed as means \pm SEM.

\section{RESULTS}

\subsection{Developmental expression of $18 \mathrm{~S}$, $\beta$-actin and of GHR genes}

Northern-blot hybridisation of muscle RNA preparations with the 18 S oligonucleotide identified the $1.8 \mathrm{~kb}$ rRNA in muscle of double-muscled and normal foetuses (Figs. 1a and 1b). Variance analysis showed that there was no effect of genetic type, a slight effect of age $(P=0.04)$, the $18 \mathrm{~S}$ rRNA level decreasing with age only in normal animals $(P<0.05)$ (Fig. 2a) and no interaction between the age and the genetic type.

Mouse $\beta$-actin cDNA is known to hybridise to actin mRNA in muscle [30, 31 ], so it was used as a control for the degree of muscle differentiation during foetal development. Northern-blot hybridisation of muscle mRNA preparation identified a $2.2 \mathrm{~kb}$ mRNA in the muscle of double-muscled and normal foetuses (Figs. 1c and 1d). The results of variance analyses of crude results obtained with $\beta$-actin or of the data obtained by using $18 \mathrm{~S}$ rRNA level as a covariable were the same. They showed an effect of age and an effect of genetic type $(P<0.001)$ and a significant interaction between these two factors. Whatever the genetic type, the $\beta$-actin mRNA levels increased regularly from 130 to 210 days pc. Their levels were higher in the ST of normal animals than of the DM animals $(P<0.001)$ especially at 170 days of foetal life, but also at 210 days pc (Fig. 2b).

Northern-blot hybridisation of foetal ST muscle RNA preparations with the bovine 


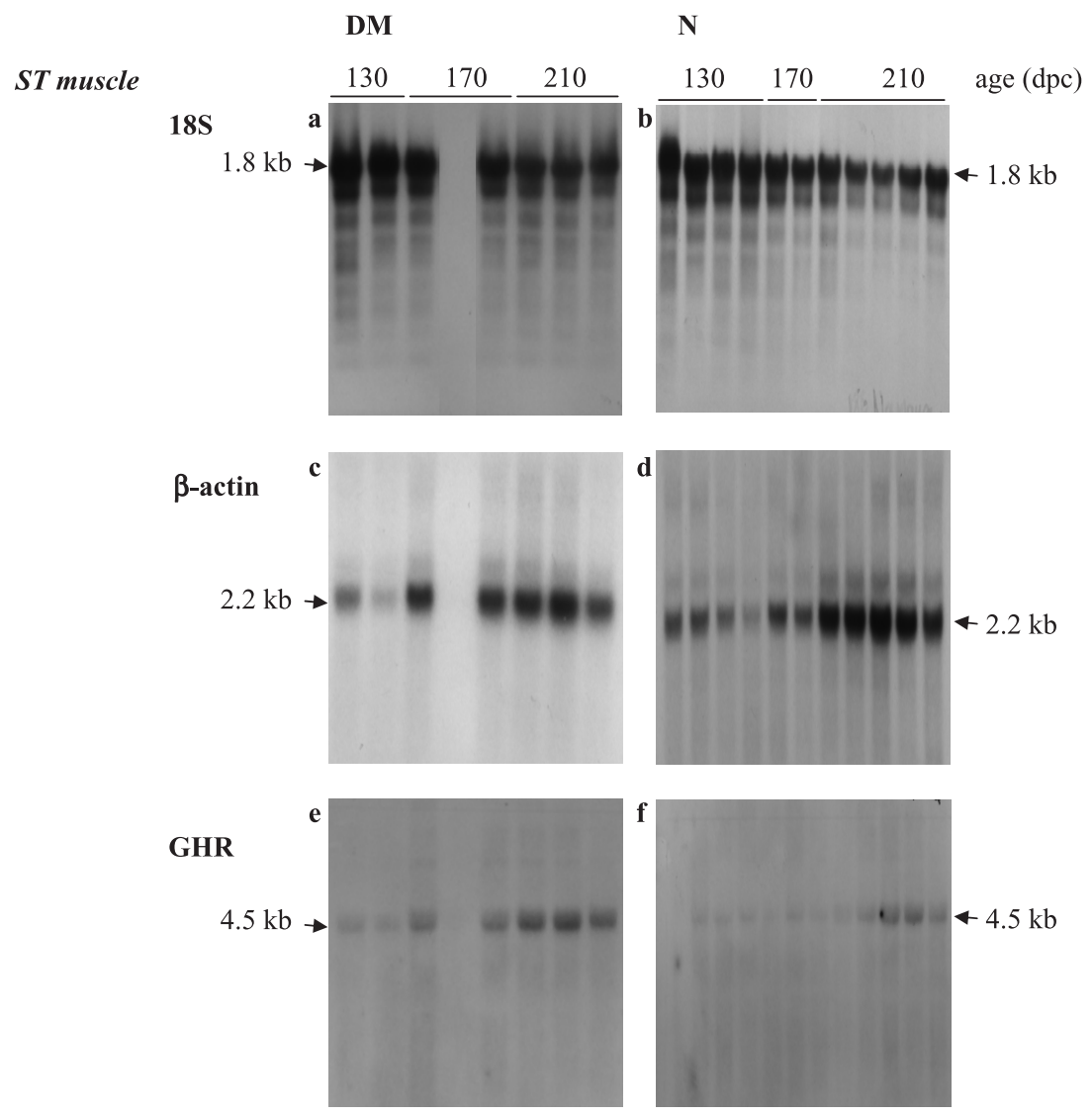

Figure 1. Northern-blot analysis of $18 \mathrm{~S}(\mathbf{a}, \mathbf{b}), \beta$-actin $(\mathbf{c}, \mathbf{d})$ and growth hormone receptor $(\mathrm{GHR})$ (e, f) gene expression in foetal semitendinosus (ST) muscle of double-muscled (DM) and normal $(\mathrm{N})$ animals of 130, 170 and 210 days post-conception (dpc).

GHR cDNA identified the $4.5 \mathrm{~kb}$ GHR mRNA (Figs. 1e and 1f). During the foetal period, the GHR mRNA was expressed at all stages analysed, in both genetic types.

Variance analysis of the crude and normalised results in ST muscle showed effects of age and genetic type $(P<0.01)$ but no interaction between these two factors. In double-muscled animals, GHR mRNA levels increased regularly and significantly $(P<0.001)$ from 130 to 210 days pc $(P<0.01)$. In normal ones, their increase was not significant. These levels were higher in the ST of DM animals than those of normal animals $(P<0.01)$ from the second third of gestation (170 dpc) (Fig. 2c).

\subsection{Localisation of GH receptor gene expression in foetal muscle}

To establish the precise intramuscular localisation of GHR gene expression in bovine muscle, we conducted an in situ hybridisation study at several foetal ages representative of the various stages of muscular development.

At 130 and $170 \mathrm{dpc}$ (the two first thirds of gestation), hybridisation with the GHR 


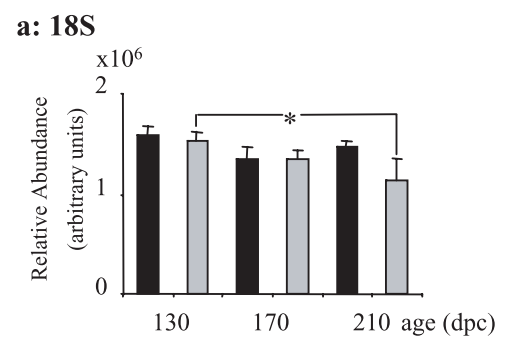

b: $\beta$-actin

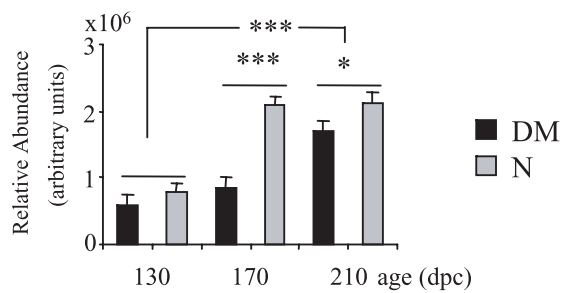

c: GHR

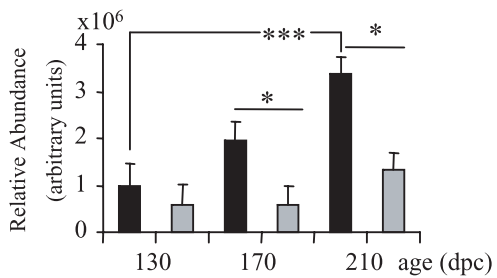

Figure 2. Results of Northern-blot analysis of $18 \mathrm{~S}$ (a), $\beta$-actin (b) and growth hormone receptor (GHR) (c) gene expression in foetal semitendinosus (ST) muscle of doublemuscled (DM) (black bars) and normal (N) (grey bars) animals at different ages postconception $(\mathrm{d} \mathrm{pc})$. The results normalised relative to $18 \mathrm{~S}$ mRNA levels are presented as means \pm sem. Asterisks indicate significantly different means between ontogenic stages of between normal and double-muscled foetuses $(* P<0.05 ; * * * P<0.001)$.

probe generated clusters of silver grains in the nuclei of muscle cells (Figs. 3.1, 3.2, 3.4 and 3.5). At the end of gestation, illustrated by the 210 days pc sample, the labelling was very abundant (Figs. 3.7 and 3.8) and as at the adult stage, the hybridisation signal was distributed throughout the cell (Figs. 4.4 and 4.5). In the connective tissue surrounding them there was no signal. Foetal liver, used as a positive tissue control, displayed a strong but diffuse GHR signal localisation (Figs. 4.1 and 4.2).

\section{DISCUSSION}

This study identified and localised GH receptor mRNA in bovine muscle during foetal development using Northern-blot and in situ hybridisation analyses. In foetal muscle, a single transcript was observed with a size of about $4.5 \mathrm{~kb}$ which is consistent with the bovine GHR transcript reported in the adult liver [25] and in foetal tissues, such as the liver, thymus, spleen, kidney and brain [32].

In this study, we demonstrate a higher $\mathrm{GH}$ receptor gene expression in the ST of double-muscled bovine foetuses compared to normal ones. It is well known that double-muscled animals have a lot of particularities, including muscle hypertrophy especially in ST muscle. Some of these particularities may be explained by GH actions demonstrated in vivo or in vitro. The greater muscle mass of DM cattle arises from an increased total number of fibres. This hyperplasia results in the hypertrophy of some muscles in DM cattle, since their mass is about twice that of other muscles before birth in N cattle. Muscle hypertrophy is general but not uniform. It is greater in some parts of the shoulder and forelimb, and especially in the proximal part of the hindlimb [2].

The effect of GH on hyperplasia has been shown in vivo by Rehfeldt et al. [16]. They showed that treatment of pregnant sows early in gestation (days 10 to 24) with porcine somatotropin increased the number of muscle fibres in skeletal muscles in the foetus resulting in higher body weight at birth. However, the mechanisms by which the GH regulates skeletal muscle growth remain unclear. GH might act concomitantly with myostatin. In fact Liu et al. [20] have shown that GH had an inhibitory effect on myostatin expression. In our model, we showed that GHR mRNA level increased 

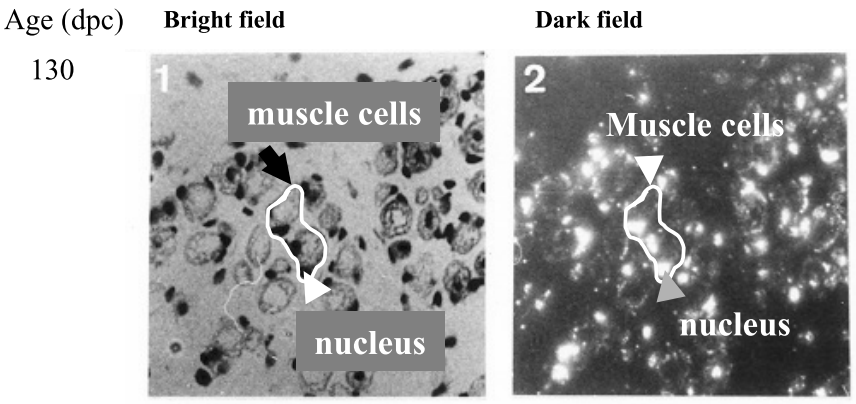

170
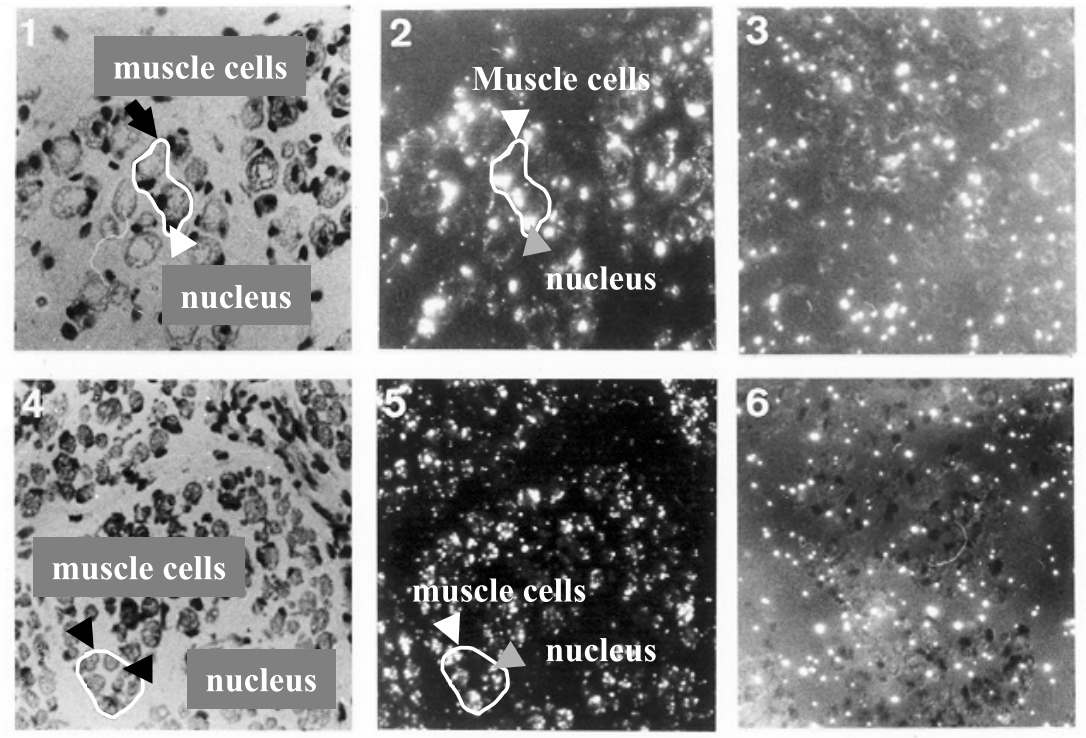

210
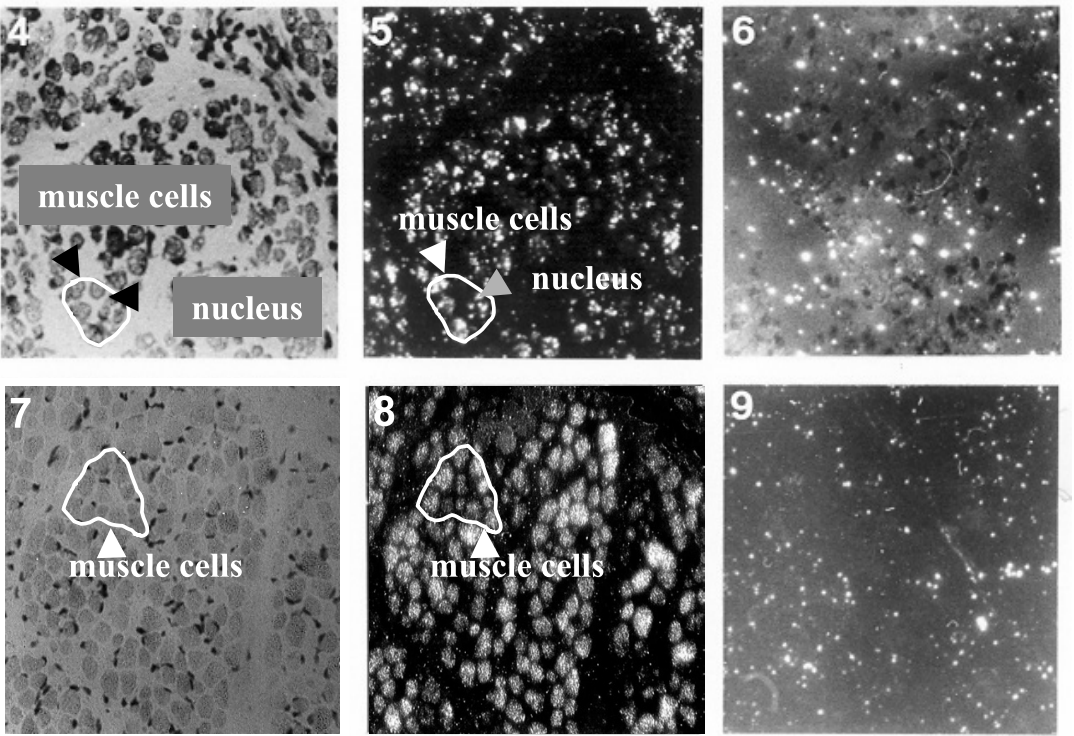

Figure 3. Localisation of the growth hormone receptor (GHR)mRNA in normal semitendinosus muscle by in situ hybridisation. Bright micrographs $(\mathbf{1}, \mathbf{4}$ and $\mathbf{7})$ exhibited muscle structure with nuclei which appeared in black, muscle cells in gray, and connective tissu in clear gray. Dark field $(2,5$ and 8) micrographs exhibited the localisation of muscle GH receptor mRNA during foetal bovine development (130 days post-conception [d pc], 1-2-3; $170 \mathrm{~d}$ pc, 4-5-6; $210 \mathrm{~d}$ pc, 7-8-9), using a ${ }^{35} \mathrm{~S}$-labelled GHR antisense riboprobe. Some positive muscle cells are surrounded. The signal (silver grains) in the form of white points appeared on dark field micrographs. At 130 and $170 \mathrm{~d} \mathrm{pc}$, it was localised in nuclei of muscle cells, at $210 \mathrm{~d} \mathrm{pc}$, it was localised throughout the muscle cells. The negative control dark field (right column) micrographs $(\mathbf{3}, \mathbf{6}$ and $\mathbf{9})$ were obtained using ${ }^{35} \mathrm{~S}$-labelled GHR sense riboprobe and showed no positive localisation above background in any region. Magnification $\times 250$.

from $130 \mathrm{dpc}$ mainly in double-muscled animals and, in another study, that myostatin mRNA expression (which was very high at $110 \mathrm{dpc}$ ) decreased considerably during the second third of gestation both in normal and double-muscled animals [22]. The increase in GHR mRNA was perhaps due to an increase in foetal GH or of the GH-like level. According to the results of Liu et al. [20], we can hypothesise, that the decrease in myostatin mRNA level was related to an increase in $\mathrm{GH}$ action, the latter being higher due to a greater expression level of the GHR. 

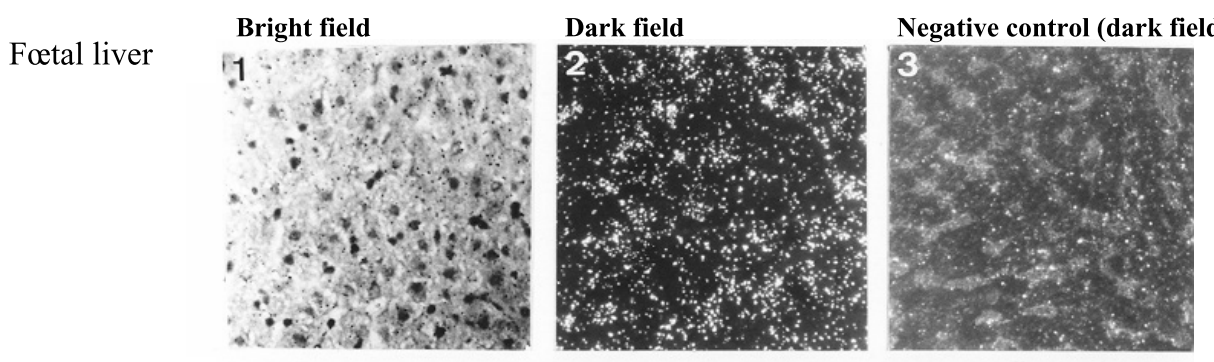

Adult muscle
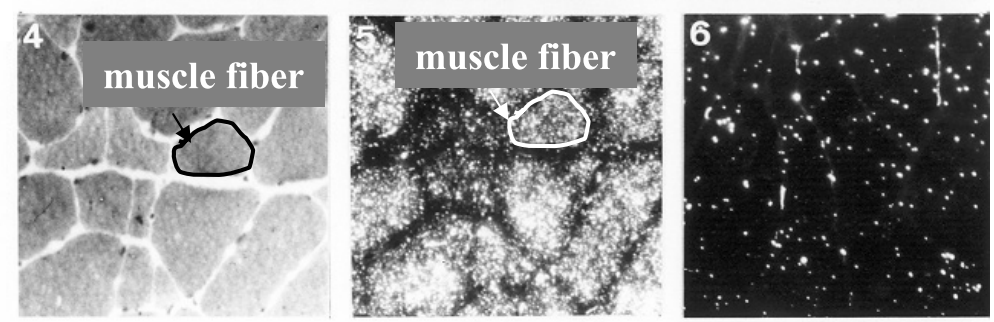

Figure 4. Localisation of growth hormone receptor (GHR)mRNA in normal foetal liver (bright field: 1, dark field: $\mathbf{2}, \mathbf{3}$ ) and in adult semitendinosus (bright field: 4, dark field: 5, 6) muscle by in situ hybridisation. The signal (silver grains) appeared in the form of white points on dark field micrographs. Foetal liver displayed a strong but diffuse GHR signal localisation. In the adult muscle, one positive muscle cell was surrounded. The labelling was high and distributed in all the cells. A ${ }^{35}$ S-labelled GHR sense riboprobe was used as the negative control in micrographs 3 and 6. There was no positive localisation above background in any region. Magnification $\times 250$.

In the double-muscled animals, the inactive myostatin might have triggered a novel muscle regulatory pathway with an up regulation of the GH system. This could explain why double-muscled animals have a more developed muscle mass than normal ones [2]. IGF, mainly IGF-II, could also be implicated in the differences between normal and double-muscled foetuses. Kocamis et al. [21] showed that IGF-II mRNA levels were significantly higher in myostatin knockout mice soleus muscles with no translation in active myostatin than in those of control mice. We can thus hypothesise, that our previous results (more IGF-II mRNA in double-muscled animals where myostatin is inactive) [8] were in agreement with those of Kocamis et al. (21) (more IGF-II mRNA in animals where there is no myostatin). It would have been interesting to discuss possible relations between IGF-II and GHR, but to our knowledge, no relation has been found in the literature between GHR mRNA abundance and the IGF-II mRNA level [33].

Another particularity of DM muscles concerns the properties of their muscle fibres. Adult animal muscles contain a higher proportion of fast-twitch glycolytic fibres (IIX fibres), which is another point on which GH might play a role. As a matter of fact, Loughna and Bates [34] found in hypophysectomised rats that $\mathrm{GH}$ treatment restored the mRNA levels for all forms of the myosin heavy chain, particularly the fast glycolytic ones. Al Hassan et al. [35] presented similar results in the rat, i.e. that the mRNA levels of GHR were greater in fast twitch (glycolytic) than in slow twitch (oxidative) muscles.

By in situ hybridisation, we observed that the GHR mRNA were only present in developing muscle bundles around nuclei during foetal life, and not in the connective 
tissue surrounding the fibres. This result was in agreement with that obtained by Mertani and Morel [36] in rats and by Mertani et al. [37] in humans. In the adult muscle, the signal was marked and homogenous not around the nuclei, but equally distributed throughout the muscle fibres. In the adult muscle, the GHR mRNA labeling was unexpected compared with the low specific GH binding observed in microsomial muscle preparations from other species [34,38].

To verify if the GHR mRNA were translated in an active GHR protein, we attempted to realise binding of ${ }^{125} \mathrm{I}$ oGH labelled both on muscle and liver microsomal preparation and on muscle sections from normal and double-muscled foetuses, but we failed (results not shown). So, we observed an apparent opposition between muscular GHR mRNA amounts and muscular $\mathrm{GH}$ specific binding. Both in adult and foetal muscle, other authors have observed the same contradiction as we did [7,36, 37, 39]. Only a few studies in adult and foetal pig skeletal muscle $[40,41]$ and in bovine embryos [19] were able to detect a specific binding of GH. By autoradiographic studies, the GH specific binding was located in the outer margins of the adult rat muscle and in local regions of the perimysial space [42]. The GH binding was restricted to small areas and could explain the very low GH binding observed if total muscle membranes were used. Another hypothesis to explain the lack of $\mathrm{GH}$ binding is that, in the foetus, another molecule is able to bind to $\mathrm{GH}$ receptor. For instance, sheep foetal liver is able to bind both ${ }^{125} \mathrm{I}$-oGH (ovine $\mathrm{GH}$ ) and ovine Placental Lactogen (oPL) [43].

In contrast to the higher GHR expression in the double-muscled animals compared to the normal ones, the $\beta$-actin gene expression was lower. This result was consistent with the pattern of expression of myosin isoforms observed by immunocytochemical detection, indicating the presence of more mature myosins in the muscles of normal than of double-muscled foetuses at the same gestational stage [6]. These observations confirm a delay in the degree of differentiation of double-muscled foetuses.

In conclusion, this study shows that double-muscled foetuses can be used to investigate the potential and direct mitogenic role of GH via its specific receptor in muscular tissue and offers a good model for understanding the transcriptional regulation of the bovine $\mathrm{GH}$ receptor gene during development. The major characteristics of double-muscled foetuses are a higher level of GHR expression at the end of gestation compared to normal animals, concomitant with a low myostatin expression and a higher level of IGF-II mRNA expression than in the normal genotype.

\section{REFERENCES}

[1] Grobet L, Royo L, Poncelet D, Pirottin D, Brouwers B, Riquet J, Schoeberlein A, Dunner S, Menissier F, Masabanda J, Fries R, Hanset $\mathrm{R}$, Georges M. A deletion in the bovine myostatin gene causes the double-muscled phenotype in cattle. Nat Genet 1997, 17: 71-74.

[2] Dumont BL. Carcass composition and muscle structure of hypertrophied animals. In: Muscular hypertrophy of genetic origin and its use to improve beef production. In: King JWB, Ménissier F (Eds), Muscle Hypertrophy of Genetic Origin and its Use to Improve Beef Production, The Hague: Martinus Nijhoff Publishers, Curr Topics Vet Anim Sci 1982, 16: 111-133.

[3] Quinn LS, Ong LD, Roeder RA. Paracrine control of myoblast proliferation and differentiation by fibroblasts. Dev Biol 1990, 140: 8-9.

[4] Gerrard DE, Judge MD. Induction of myoblast proliferation in L6 myoblast cultures by foetal serum of double-muscled and normal cattle. J Anim Sci 1993, 71: 1464-1470.

[5] Picard B, Depreux F, Geay Y. Muscle differentiation of normal and double-muscled bovine foetal myoblasts in primary culture. Basic Appl Myol 1998, 8: 197-203.

[6] Picard B, Gagnière H, Robelin J, Geay Y. Comparison of the foetal development of muscle in normal and double-muscled cattle. J Muscle Res Cell Motil 1995, 16: 626-639. 
[7] Florini JR, Ewton DZ, Coolican SA. Growth hormone and the insulin growth factor system in myogenesis. Endocr Rev 1996, 17: 481517.

[8] Listrat A, Belair L, Picard B, Djiane J, Jammes H. Insulin-like growth factor-II messenger ribonucleic acids (IGF-II) expression during skeletal muscle development of double muscled and normal bovine foetuses. Reprod Nut Dev 1999, 39: 113-124.

[9] Chard T. Hormonal control of growth in the human foetus. J Endocrinol 1989, 123: 3-9.

[10] Heggestard CB, Wells LJ. Experiments on the contribution of somatotrophin to prenatal growth in the rat. Acta Anat 1965, 12: 348349 .

[11] Jost A. Anterior pituitary function in foetal life. The Pituitary Gland 1966, 2: 329-323.

[12] Gluckman PD. The role of pituitary hormones, growth factors and insulin in the regulation of foetal growth. In: Clarke JR (Ed), Oxford Reviews of Reproductive Biology. Clarendon Press-Oxford, 1986, p 1-60.

[13] Strain AJ, Hills DJ, Swenne I, Milner RDG. Regulation of DNA synthesis in human foetal hepatocytes by placental lactogen, growth hormone and IGF1/SmC. J Cell Physiol 1987, 132: 33-40.

[14] Swenne I, Hills DJ, Strain AJ, Milner RDG. Growth hormone regulation of SmC/IGF1 production and DNA replication in foetal rat islets in tissue culture. Diabetes 1987, 36: 288-294.

[15] Slootweg MC, Van Buhl-Offers SC, HermannErlee MPM, Van der Meer JM, Duursma SA. Growth hormone is mitogenic for foetal mouse osteoblasts but not for undifferentiated bone cells. J Endocrinol 1988, 116: R11-R13.

[16] Rehfeldt C, Fiedler I, Weikard R, Kanitz E, Ender K. It is possible to increase skeletal muscle fibre number in utero. Biosci Reprod 1993, 13: 213-220.

[17] Adams TE, Baker L, Fiddes RJ, Brandon MR The sheep growth hormone receptor: Molecular cloning and ontogeny of mRNA expression in the liver. Mol Cell Endocrinol 1990 , 73: $135-145$.

[18] Lucy MC, Boyd CK, Koenigsfeld AT, Okamura CS. Expression of somatotropin receptor messenger ribonucleic acid in bovine tissues. $\mathrm{J}$ Dairy Sci 1998, 81: 1889-1895.

[19] Kölle S, Stojkovic M, Prelle K, Waters M, Wolf E, Sinowatz F. Growth hormone (GH)/ $\mathrm{GH}$ receptor expression and $\mathrm{GH}$-mediated effects during early bovine embryogenesis. Biol Reprod 2001, 64: 1826-1834.
[20] Liu W, Thomas SG, Asa SL, GonzalesCadavid N, Bhasin S, Ezzat S. Myostatin is a skeletal muscle target of growth hormone anabolic action. J Clin Endocrinol 2003, 88: 5490-5496.

[21] Kocamis H, Gahr SA, Batelli L, Hubbs AF, Killerfer J. IGF-I, IGF-II and IGF-receptor-1 transcript and IGF-II protein expression in myostatin knockout mice tissues. Muscle Nerve 2002, 26: 55-63.

[22] Deveaux V, Picard B., Bouley J, CassarMalek I. Localisation of myostatin expression during bovine embryogenesis in vivo and in vitro. Reprod Nutr Dev 2003, 43: 527-542.

[23] Ménissier F. Advantages of using doublemuscled sires in crossbreeding and the selection of a specialised double-muscled sire line in France. In: King JWB, Ménissier F (Eds), Muscle Hypertrophy of Genetic Origin and its Use to Improve Beef Production, The Hague, Martinus Nijhoff Publishers, Curr Topics Vet Anim Sci 1982, 16: 480-536.

[24] Puissant C, Houdebine LM. An improvement of the single-step method of RNA isolation by acid guanidinium-thiocyanate-phenol-chloroform extraction. Biotechniques 1990, 8: 148149.

[25] Hauser SD, McGrath MF, Collier RJ, Krivi GG. Cloning and in vivo expression of bovine growth hormone receptor mRNA. Mol Cell Endocrinol 1990, 72: 187-200.

[26] Hocquette JF, Graulet B, Castiglia-Delavaud C, Bornes F, Lepetit N, Ferré P. Insulin-sensitive glucose transporter transcript levels in calf muscles assessed with a bovine Glut4 cDNA fragment. Int $\mathrm{J}$ Biochem Cell Biol 1996, 28: 795-806.

[27] Lyons GE, Ontell M, Cox R, Sassoon D, Buckingham $\mathrm{M}$. The expression of myosin genes in the developing skeletal muscle in the mouse embryo. J Cell Biol 1990, 111: 14651476.

[28] SAS. SAS/STAT guide for personal computer. 1996.

[29] Hocquette JF, Brandstetter AM. Common practice in molecular biology may introduce statistical bias and misleading biological interpretation. J Nutr Biochem 2002, 13: 370 377.

[30] Vandekerckhove J, Weber K. The complete amino acid sequence of actins from bovine aorta, bovine heart, bovine fast skeletal muscle and rabbit slow skeletal muscle. Differentiation 1979, 14: 123-133.

[31] Alonso S, Minty A, Bourlet Y, Buckingham M. Comparison of three actin-coding sequences in the mouse; Evolutionary Relationships between the actin genes of Warm-blooded vertebrates. J Mol Evol 1986, 23: 11-22. 
[32] Scott P, Kessler MA, Schuler LA. Molecular cloning of the bovine prolactin receptor and distribution of prolactin and growth hormone receptor transcripts in foetal and utero-placental tissues. Mol Cell Endo 1992, 89: 47-58.

[33] Forhead AJ, Li J, Gilmour RS, Dauncey MJ, Fowden AL. Thyroid hormones and the mRNA of the GH receptor and IGFs in skeletal muscle of foetal sheep. Am J Physiol Endocrinol Metab 2002, 282: E80-E86.

[34] Loughna PT, Bates PC. Interaction between growth hormone and nutrition in hypophysectomised rats: skeletal muscle myosin heavy chain mRNA levels. Biochem Biophys Res Comm 1994, 198: 97-102.

[35] Al Hassan C, Desplanches D, Mayet-Sornet M-H, Raccurt M, Jegou S, Morel G. Growth hormone receptor expression in atrophying muscle fibres of rats. Endocrinology 2003, 144: 3692-3697.

[36] Mertani HC, Morel G. In situ gene expression of growth hormone $(\mathrm{GH})$ receptor and $\mathrm{GH}$ binding protein in adult male rat tissues. Mol Cell Endocrinol 1995, 109: 47-61.

[37] Mertani HC, Delehaye-Zervas MC, Martini JF, Postel-Vinay MC, Morel G. Localisation of growth hormone receptor messenger RNA in human tissues. Endocrine 1995, 3: 135-142.
[38] Posner BI, Kelly PA, Shiu RPC, Friesen HG. Studies of insulin, growth hormone and prolactin binding: tissue distribution, species variation and characterization. Endocrinology 1974, 98: 645-652.

[39] Jennische E, Anderson GL. Expression of GH receptor mRNA in regenerating skeletal muscle of normal and hypophysectomyzed rats. An in situ hybridisation study. Acta Endocrinol 1991, 125: 595-602.

[40] Schnoebelen-Combes S, Louveau I, PostelVinay MC, Bonneau M. Ontogeny of GH receptor and $\mathrm{GH}$-binding protein in the pig. $\mathrm{J}$ Endocrinol 1996, 148: 249-255.

[41] Louveau I, Etherton TD. Characterization of somatotropin binding sites in pig skeletal muscle. J Anim Sci 1992, 70: 1801-1805.

[42] Zanelli J, Ball C, Ayling C, Sutcliffe N, Stenning B, Moreland B, Schulster D. Long-term administration of human growth hormone to the rat induces ${ }^{125}$ I labelled-growth hormone binding sites in skeletal muscle. J Endo 1989, 121: Suppl 1, abstract 44.

[43] Klempt M, Bingham B, Breier BH, Baumbach WR, Gluckman PD. Tissue distribution and ontogeny of growth hormone receptor messenger ribonucleic acid and ligand binding to hepatic tissue in the midgestation sheep foetus. Endocrinology 1993, 132: 1071-1077. 